\title{
Implementation of Legalized Document Order System For Graduates Muria Kudus University By Utilizing REST API (Application Programming Interface)
}

\author{
Fajar Nugraha ${ }^{1}$, Rhoedy Setiawan ${ }^{2}$, Eko Darmanto ${ }^{3}$, Anteng Widodo ${ }^{4}$, Yuniarsi Rahayu $^{5}$ \\ \{fajar.nugraha@umk.ac.id ${ }^{1}$, rhoedy.setiawan@umk.ac.id ${ }^{2}$, eko.darmanto@umk.ac.id ${ }^{3}$ \} \\ Universitas Muria Kudus, Gondang Manis PO. BOX 53 Bae Kudus, Indonesia ${ }^{1234}$ \\ Faculty of Computer Science, Universitas Dian Nuswantoro ${ }^{5}$
}

\begin{abstract}
Improved service to users is a need for an information system development. Muria Kudus University graduates who need legalized legalization of academic documents both diplomas and transcripts are often constrained by time and location to legalize the documents. This study aims to develop legalized ordering system of academic documents to improve services to the graduates of Muria Kudus University especially to graduates who are currently out of town who need academic document services both diplomas and transcripts. The system adopts the REST API (Application Programming Interface) provided from some freight forwarding services to maintain the accuracy of data shipping costs legalizing academic documents. The result of this research is legalized ordering system document designed using UML which can be used as legalized ordering service of academic document by utilizing REST API technology to show the accuracy of shipping cost from some goods delivery service.
\end{abstract}

Keywords: graduates, legalize documents, REST API.

\section{Introduction}

The development of Internet technology is an opportunity that can be used to improve the information system services. A college of course not only provide services for students who are still active but also services to the graduates. Muria Kudus University graduates are scattered in various cities are often constrained by the legalization of academic documents both diplomas and transcripts that must come directly to legalize the document. This is certainly a problem if the graduates have limited time and location to perform legalization process of academic documents.

Based on these problems, this research will develop a legalized document ordering system that will be used by graduates as an alternative to legalizing academic documents. This online legalized service uses the graduate website as the interface. The graduates simply fill in the necessary data in the process of filing reservations legalisir academic documents. This legalized ordering service system utilizes REST API (Application Programming Interface) from several freight forwarding providers to display the type of freight service and shipping costs. Data shipping costs will be directly taken from the web of each freight forwarder to maintain the validity of the data and so that the shipping costs can be directly known by the 
legalized ordering of academic documents. This research is expected to help and provide convenience for the graduates of Muria Kudus University to legalize academic documents.

The research related to the legalized system of online diploma is the research done to design the legalized system of diploma in the Faculty of Teacher Training and Education Ahmad Dahlan University. Where in the legalization of the diploma can only be done directly by coming to the place, so that the graduates must come more than once directly to the service to do the legalization of diplomas and academic transcripts. The purpose of this study is to design the online system as a graduate media services for legal purposes copy of diploma and academic transcript for graduate of Faculty of Teacher Training and Education Universitas Ahmad Dahlan [1].

In a study conducted at the Faculty of Engineering, State University of Padang on the design of legal information systems web-based documents. The study explains the process of managing the diploma files done manually, including in recording details of the legalized documents. Some of these problems cause the absence of certainty of time in the process of legalizing the document because there is no system that can provide information about the legalization filing status documents [2].

Research on REST API (Application Programming Interface) is used in research conducted on android-based academic portal at Duta Wacana Christian University. Academic service data is stored and retrieved from multiple server databases so REST-API are required are required to connect between platforms of both sides to be delivered properly [3].

\section{Problem formulation}

Formulation of problem in implementation of legalized document order system for graduates Muria Kudus University By Utilizing REST API (Application Programming Interface) is how to develop legalized document service for graduates Muria Kudus University by using REST API (Application Programming Interface) in order to improve service to the graduates will require legalized services of academic documents without having to come directly to Muria Kudus University. How to use the REST API to display the shipping costs of several freight forwarding services to maintain the accuracy of the shipping cost data in accordance with what will be displayed on an online legalized service system.

\section{Research Methods}

The model used to design a legalized ordering system for Muria Kudus University using REST API (Application Programming Interface) using Object Oriented Design (OOD) with system design tools using Unified Modeling Language (UML). Using OOD modeling in system design will result in risk in developing a software system to be implemented [4]. 


\subsection{System design}

The design of legalized document order system for graduates Muria Kudus University by utilizing REST API (application programming interface) will use the web that is integrated with the graduate website. The representation of this legalized service system will be explained through the use case. There are three actors who will play a role in this system ie admin, user or graduate and delivery service that will send legalized documents. Admin can perform legalized type of management, delivery service, payment account and report of legalized list.

To use the legalized ordering system of this document the user or graduate must log on the graduate portal. As a user, Graduates will have a menu of submissions or legalized messages containing data related to the reservation of academic documents to be legalized as well as a list of legalized which is a list of legalized submissions that have been submitted. Figure 1 describes the use case of an online legalized service system.

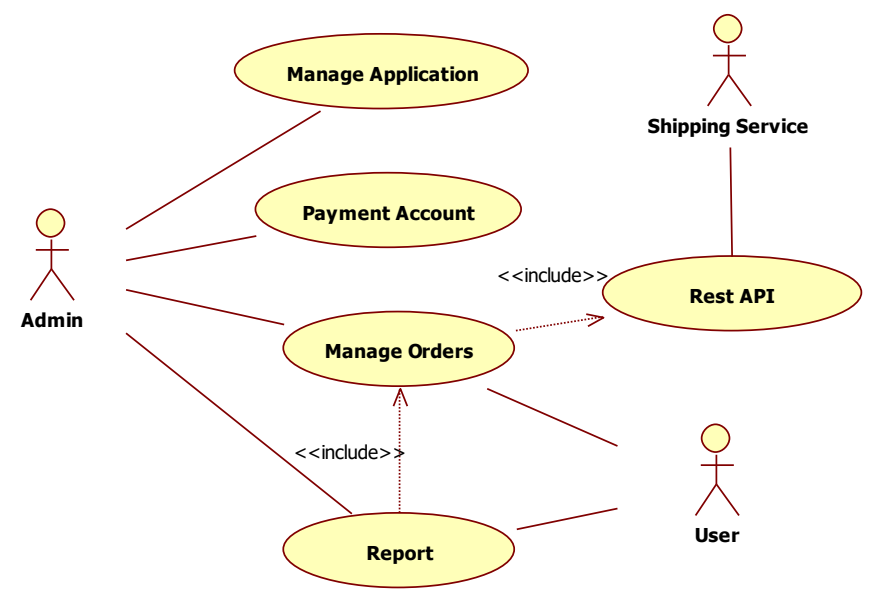

Fig. 1. Use case diagram.

\subsection{REST API}

The REST API Web service has a very important role as it affects the overall performance of a distributed web app [5]. The design in the REST architecture is the client server, where there is communication between the client side that sends a request message to the server side that will respond. Such communication necessarily requires a protocol that is understandable from the client or server side [6]. Below is a REST documentation for displaying data on shipping service from the legalized document ordering system. 


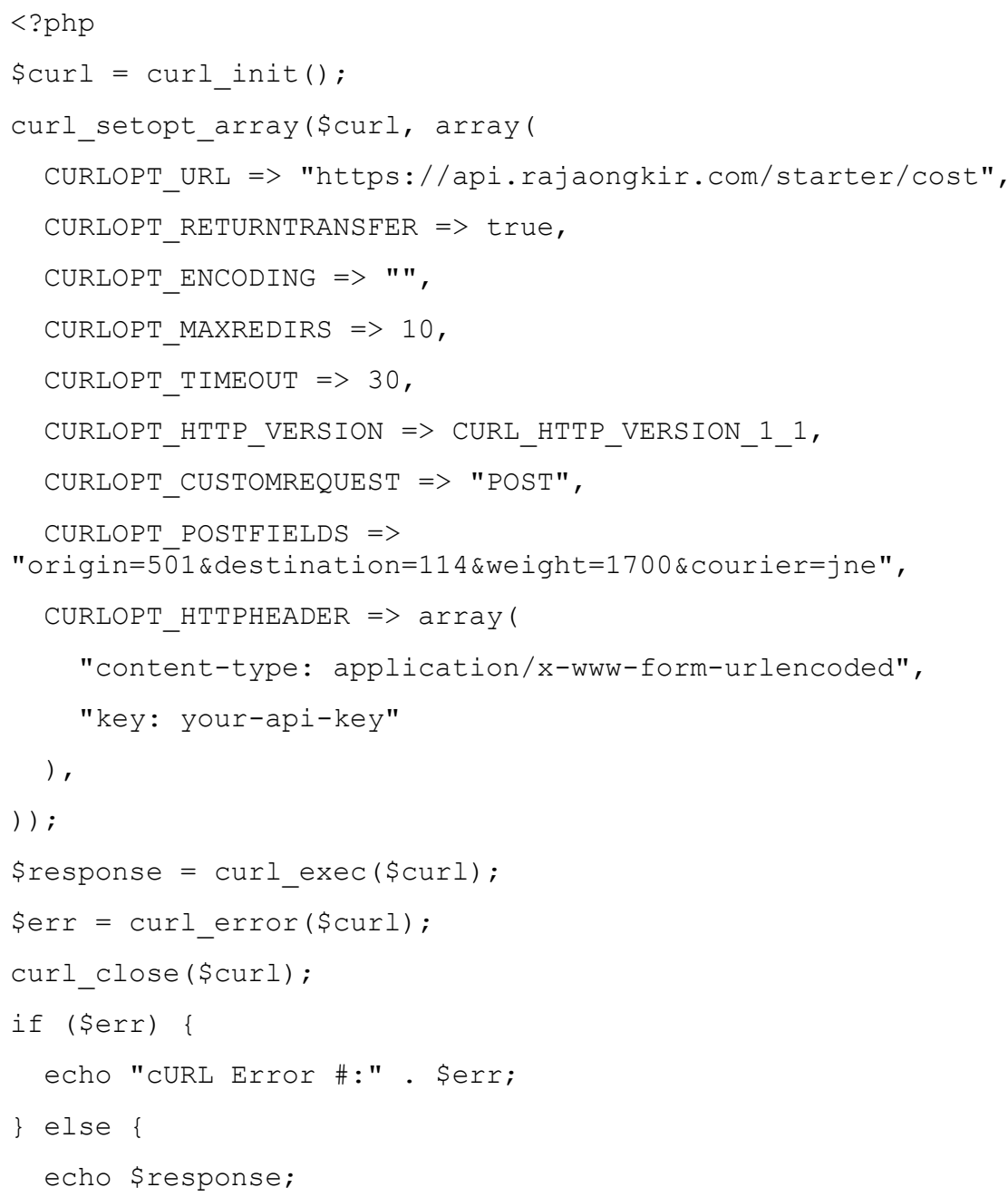

\section{Research Results}

The result of this research is a legalized document order system that can be used to serve the needs of graduates who need legalized services of academic documents. This service can be accessed through web graduates with address http://alumni.umk.ac.id/. This service is developed in order to improve the service to the graduates of Muria Kudus University especially to graduates who are currently out of town who have limited time and location to manage legalized academic documents such as diplomas and transcripts directly. In addition, this service is a form of MSE commitment in providing the best service for its graduates. 
Figure 2 is a List of legalized document order management on the legalized document ordering system.

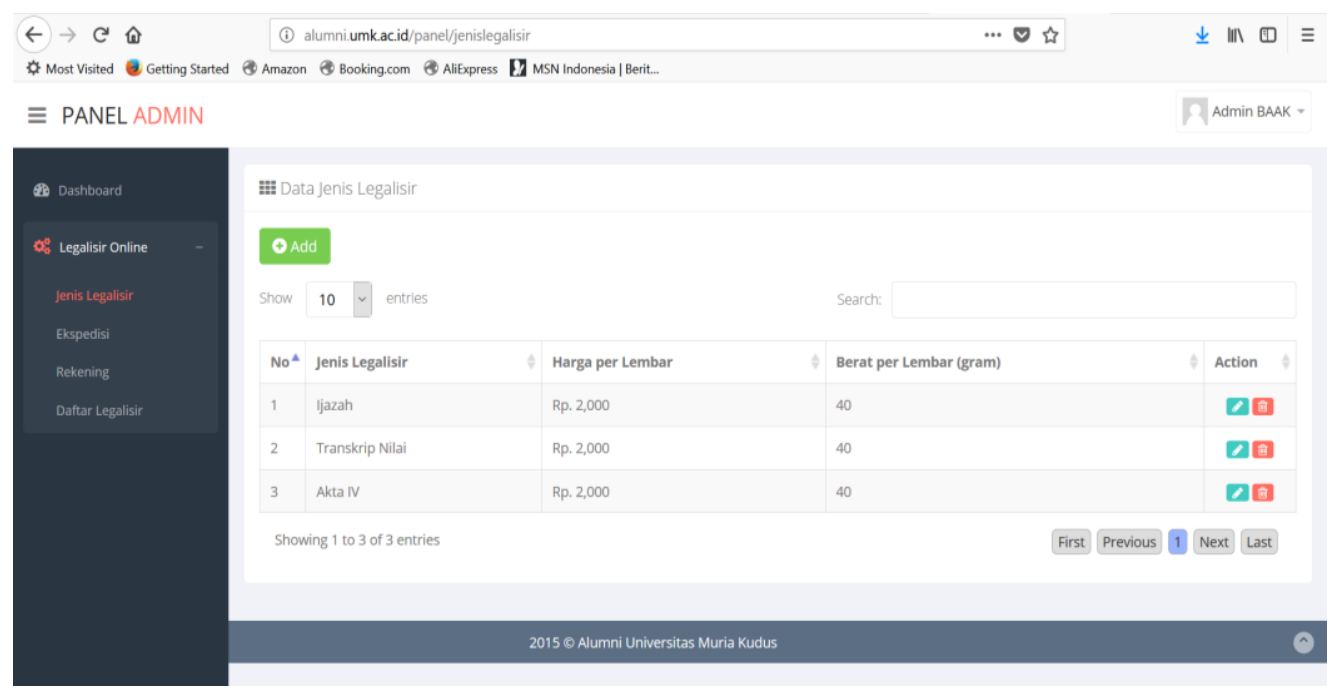

Fig. 2. List of legalized document order management.

Figure 3 is a list of displaying the order form legalizing document using the REST API from the shipping service, data fields that must be completed at the time of submitting legalized documents. These data include legalized items, legalized amount and stuffing service delivery by the shipping services that use to obtain data of shipping service cost in accordance with that determined by each expedition services.
$\leftarrow \rightarrow \mathrm{C}$ 会
(i) alumni.umk.ac.id/orderlegalisit
$67 \% \quad \ldots \vee$
Most Visited Getting Started Amazon Booking.com Aliexpress DI MSN Indonesia|Berit...

$\equiv$ ALUMNI.UMK.AC.ID | UNIVERSITAS MURIA KUDUS

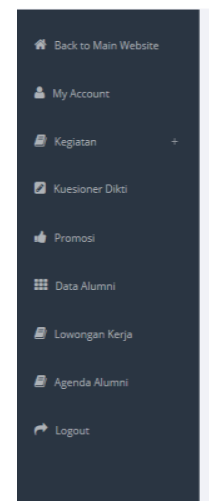

a Pesan Legallis

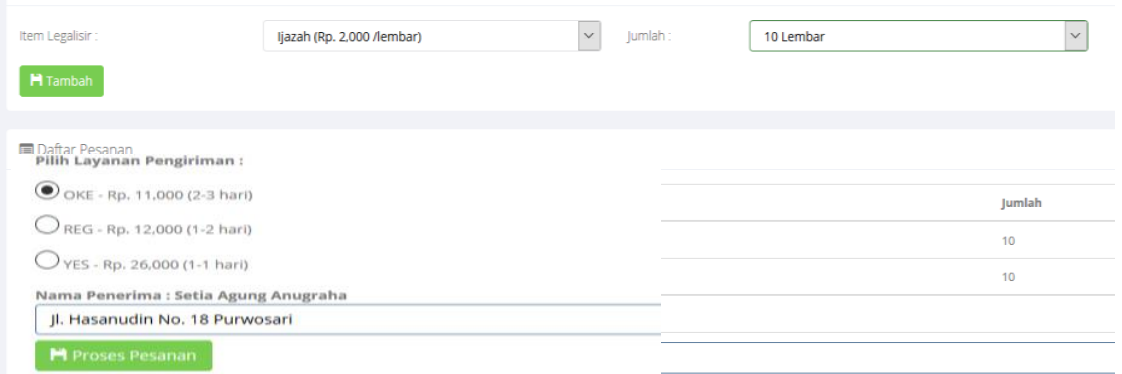

J1. Hasanudin No. 18 Purwosari

A Proses Pesanan 
Fig. 3. Displaying the order form legalizing document using the REST API from the shipping service.

Figure 4 is the display of the order acceptance confirmation form. This form is a sign that graduates have received legalized documents of their academic documents. The entire process of filing a legalized academic document has been completed processed by ending pressing the order accept confirmation button.

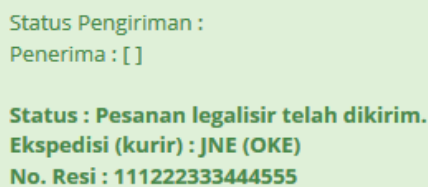

\section{E}

Fig. 4. Order acceptance confirmation form.

\section{Conclusion}

Research on legalized document order system for graduates Muria Kudus University by utilizing REST API (Application Programming Interface) can be used to improve the service to graduates who can not attend the campus for academic documents. This system utilizes the REST API to integrate data from the shipping service to maintain the accuracy of the shipping cost data from various shipping service providers. The REST API Web service has a very important role as it affects the overall performance of a distributed web app.

\section{References}

[1] Suparman and A. Pranolo, "Desain Sistem Layanan Online Legalisir Ijazah dan Transkrip Akademik di FKIP Universitas Ahmad Dahlan," Informatika, vol. 8, no. 2, pp. 953-964, 2014.

[2] Fitri Kurnia, Zulhendra, and K. Denny, "Perancangan Sistem Informasi Legalisir Dokumen Berbasis Web Di Fakultas Teknik Universitas Negeri Padang," J. Vokasional Tek. Elektron. Inform., vol. 2015, no. 2, pp. 56-63, 2015.

[3] Y. K. Kurniawan, Y. Oslan, and H. Kristanto, "Implementasi Rest - Api Untuk Portal Akademik

Ukdw Berbasis Android,” J. EKSIS, vol. 6, pp. 29-40, 2013.

[4] G. Booch, R. a. Maksimchuk, M. W. Engle, B. J. Young, J. Conallen, and K. a. Houston, ObjectOriented Analysis and Design with Applications, vol. 1, no. 11. 2007.

[5] G. M. Tere, R. R. Mudholkar, and B. T. Jadhav, "Improving Performance of RESTful Web Services,” IOSR J. Comput. Sci., vol. 2014, pp. 12-16, 2014.

[6] S. Mumbaikar and P. Padiya, "Web Services Based On SOAP and REST Principles," Int. J. Sci. Res. Publ., vol. 3, no. 1, pp. 2250-3153, 2013. 